\title{
EUFEMISME DAN DISFEMISME PADA JUDUL BERITA SURAT KABAR HARIAN BALIKPAPAN POS PERIODE APRIL-MEI 2018
}

\author{
Rezeki Rika Jayanti ${ }^{1}$, Nurliani Maulida ${ }^{2}$, Ari Musdolifah ${ }^{3}$ \\ Universitas Balikpapan $^{1}$, Universitas Balikpapan ${ }^{2}$, Universitas Balikpapan ${ }^{3}$ \\ Pos-el: rezekirika23@gmail.com ${ }^{1}$, nurliani.maulida@uniba-bpn.ac.id ${ }^{2}$, arymusdolifah@uniba-bpn.ac.id ${ }^{3}$
}

\begin{abstract}
ABSTRAK
Penelitian ini dilatarbelakangi adanya judul berita surat kabar mengandung gaya bahasa yang digunakan oleh jurnalistik. Salah satu gaya bahasa yang digunakan oleh para jurnalistik ialah penggunaan eufemisme dan disfemisme. Eufemisme ialah ungkapan bahasa dengan makna halus. Sedangkan disfemisme ialah ungkapan bahasa dengan makna kasar atau kurang sopan. Mendeskripsikan sebuah kata adalah eufemisme atau disfemisme perlu digunakan pendekatan semantik leksikal. Semantik leksikal lebih memfokuskan makna pada yang terdapat pada kamus. Adapun tujuan penelitian ini ialah mendeskripsikan bentuk dan manfaat dari penggunaan eufemisme dan disfemisme pada judul berita surat kabar harian BALIKPAPAN POS periode April-Mei 2018. Penelitian ini menghasilkan data kualitatif deskriptif. Data yang digunakan berbentuk kata. Pengumpulan data dilakukan dengan menggunakan teknik simak dan teknik catat. Selanjutnya, data dalam penelitian ini dianalisis menggunakan semantik dengan didasari kajian eufemisme dan disfemisme oleh Sutarman. Hasil penelitian ini menunjukkan bahwa eufemisme dan disfemisme digunakan dalam judul berita surat kabar harian BALIKPAPAN POS periode April-Mei 2018 dengan data berjumlah 36 buah. Data eufemisme sebanyak 17 data dan data disfemisme sebanyak 19 data. Penggunaan disfemisme berbentuk kata benda terdiri 4 data, eufemisme berbentuk kata kerja terdapat 13 data dan disfemisme berbentuk kata sifat terdiri 2 data, penggunaan disfemisme ini bermanfaat untuk penulisan judul berita di media massa.
\end{abstract}

Kata Kunci: Eufemisme Dan Disfemisme, Surat Kabar.

\section{ABSTRACT}

Research "Euphemism and Dysfemism on the Title of Newspaper News BALIKPAPAN POS period April-May 2018" against the background of the newspaper news title contains the style of language used by journalism. One style of language used by journalists is the use of euphemism and dysfemism. Euphemism is the expression of language with subtle meanings. While dysfemism is the expression of language with rough or impolite meanings. Describing a word is euphemism or dysfemism needs to be used a lexical semantic approach. Lexical semantics focus more on what is contained in the dictionary. The purpose of this study is to describe the form and benefits of the use of euphemism and dysfemism in the headline news of the BALIKPAPAN POS daily newspaper for the April-May 2018 period. This study produced descriptive qualitative data. The data used is in the form of words. Data collection is done using note-taking techniques and note-taking techniques. Furthermore, the data in this study were analyzed using semantics based on studies of euphemism and dysfemism by Sutarman. The results of this study indicate that euphemism and dysfemism are used in the headline news of the BALIKPAPAN POS daily newspaper for the April-May 2018 period with a total of 36 data. Data on euphemism as many as 17 data and data on dysfemism as much as 19 data. The use of euphemisms in the form of nouns consists of 6 data, in the form of verbs consisting of 8 data and adjective euphemisms 3 data, the use of euphemisms is useful for modesty and comfort. The use of disfemism in the form of nouns consists of 4 data, verb-shaped euphemisms, there are 13 data and adjective-shaped disfemism consisting of 2 data, the use of dysfemism is useful for writing news headlines in the mass media

Keywords: Euphemism And Dysfemism, Newspapers. 


\section{PENDAHULUAN}

Bahasa merupakan alat komunikasi masyarakat untuk menyampaikan pesan secara langsung maupun tidak langsung. Dengan bahasa, masyarakat mudah untuk mengekspresikan suatu pesan agar tujuannya dapat tersampaikan dengan baik. Aminuddin (Sutarman, 2013, p. 2) menjelaskan bahwa bahasa pada hakikatnya merupakan simbol- simbol abstrak yang digunakan dalam kehidupan sehari-hari untuk merekam realitas yang dilihat, didengar, dirasakan, dialami, dilakukan, dan bahkan dipikirkan manusia.

Penggunaan bahasa secara tulis dilakukan jurnalistik dengan gaya bahasa yang beraneka ragam. Salah satunya penggunaan gaya Bahasa eufemisme dan disfemisme. Eufemisme merupakan pemakaian kata atau bentuk lain untuk menggantikan kata kasar atau kata yang kurang sopan. Selain untuk memperhalus kata-kata, bahasa juga memiliki ungkapan kasar atau makian yang kurang sopan guna mengkritik bahkan menyindir suatu kondisi tertentu yang dinamakan disfemisme. Disfemisme banyak ditemukan pada judul berita surat kabar harian guna menarik konsumen penasaran pada berita yang dimuat.

Penelitian ini dilakukan karena judul berita merupakan daya tarik utama dalam suatu media khususnya surat kabar. Judul berita pada surat kabar bervariasi dan beragam. Hal itu dilakukan untuk menjadi daya tarik berita yang terdapat di dalam surat kabar. Penggunaan eufemisme dan disfemisme ini tidak terlepas pada berbagai makna yang terkandung di dalamnya. Serta, manfaat penggunaan eufemisme dan disfemisme pada judul berita.

Fokus masalah dari penelitian ini, yaitu bentuk dan manfaat yang terkandung dalam penggunaan eufemisme dan disfemisme pada judul berita surat kabar BALIKPAPAN POS yang banyak ditemukan sebagai ungkapan pada peristiwa, dan kondisi yang menjadi berita di surat kabar. Eufemisme dan disfemisme ditentukan berdasarkan makna kata atau referensi yang menjadi indikator rumusan masalah.

Aminuddin (2013, p. 2) menjelaskan bahwa bahasa merupakan pemapar realitas. Semua kejadian yang ada di sekitar manusia direkam dan diabstraksikan dalam bentuk bahasa, kemudian disampaikan kepada orang lain juga menggunakan media bahasa.

Tarigan (2013, p. 4) menyatakan bahwa bahasa adalah bahasa indah yang digunakan untuk meningkatkan efek dengan jalan memperkenalkan serta membandingkan suatu benda atau hal tertentu dengan benda atau hal lain yang lebih umum. Secara singkat penggunaan gaya bahasa tertentu dapat mengubah serta menimbulkan konotasi tertentu.

Chaer (2010, p. 2) menyatakan bahwa bahasa jurnalistik atau bahasa Indonesia ragam jurnalisitik juga mempunya ciri-ciri sendiri yang membedakannya dengan ragam- ragam bahasa lainnya. Ciri-ciri ragam bahasa jurnalisitik adalah sesuai dengan tujuan tulisan jurnalisitik dan siapa pembaca ragam jurnalistik itu.

Barus (2011, p. 21) menjelaskan bahwa dalam praktik jurnalistik, berita menduduki posisi utama. Hampir seluruh isi surat kabar adalah berita. Bahkan ada yang menganggap iklan itu juga berita tentang produk dan jasa. Namun, inilah yang disebut dengan berita dalam arti luas. Berita merupakan suatu kejadian aktual yang diperoleh wartawan untuk dimuat dalam surat kabar. 
Analisis dalam penelitian ini dilakukan dengan menggunakan teori semantik. Tarigan (2013, p. 7) menyatakan bahwa semantik adalah menelaah lambang atau tanda yang menyatakan makna, hubungan makna satu dengan yang lain, dan pengaruhnya terhadap manusia dan masyarakat. Semantik mencakup kata-kata, perkembangan,dan perubahannya. Muslich (2007, p.5) menyatakan bahwa kata adalah satuan ujaran bebas terkecil yang bermakna. Kata dapat berdiri sendiri sebagai ujaran lengkap. Selain itu, kata dapat disisipi dengan unsur lain untuk menjadi sebuah kalimat. Contoh kata yaitu: lelaki dan jantan. Dua kata tersebut dapat berdiri sendiri. Namun juga dapat disisipi dengan unsur lain untuk menjadi sebuah kalimat.

Sutarman (2013, p. 47) menyatakan bahwa eufemisme atau eufemismus diturunkan dari kata Yunani "eufhemiein" yang berarti 'mempergunakan kata-kata dengan arti yang baik atau dengan tujuan yang baik’ Allan dan Burridge (1991, p. 11) mendefinisikan eufemisme adalah penggunaan istilah untuk mengganti ekpresi yang kurang pantas untuk menghindari kemungkinan kehilangan muka, baik orang yang diajak bicara, maupun pihak ketiga (yang mendengarkan).

Manfaat eufemisme, menurut Sutarman (2013, p. 110) menyatakan bahwa kesopanan adalah upaya yang dilakukan agar dinilai positif oleh orang lain melalui sikap, perbuatan, perkataan, maupun penampilan. Kesopanan ini berkembang menjadi sebuah norma yang berlaku di masyarakat.

Allan \& Burridge (1991, p.26) menjelaskan bahwa disfemisme adalah kata atau frase yang berkonotasi menyakitkan atau mengganggu baik bagi orang yang diajak bicara dan/atau orang yang dibicarakan serta orang yang mendengarkan ungkapan tersebut. Kata atau frase yang sengaja digunakan untuk menyinggung atau menekankan suatu pernyataan dengan bahasa yang kasar.

Sutarman (2013, pp. 115-116) menyatakan bahwa disfemisme merupakan penggunaan kata-kata yang kasar, emosional, dan membangkitkan emosi pihak yang membaca atau mendengar. Penggunaannya tidak terbatas pada hal-hal yang menyangkut emosional penuturnya, misalnya memaki, mengumpat, memarahi, membentak, dan lain-lain.

Manfaat dari disfemisme sebagai penulisan judul berita di media massa adalah untuk menjadi daya tarik para pembaca. Salah satu strateginya adalah dengan varian bahasa yang menarik yaitu disfemisme.

Penelitian relevan pertama oleh Elisa Nurul Laili Disfemisme pada Wacana Lingkungan : Sebuah Kajian Ekolinguistik Kritis dalam Media Massa di Indonesia dalam jurnal ISSN 2085-9554. Penelitian relevan yang kedua oleh Khasan, Sumarwati, Setiawan Pemakaian Disfemisme dalam Berita Utama Surat Kabar Joglo Semar dalam jurnal ISSN 12302-6405. Vol 2 nomor 3. Penelitian yang ketiga oleh Samsul Bahri Eufemisme dan Disfemisme dalam Teks Berita pada Surat Kabar Pikiran Rakyat sebagai Bahan Pembelajaran Bahasa Indonesia di SMA serta Model Pembelajarannya volume 3 nomor 15. Penelitian keempat oleh Meilasari, Nababan, Djatmika analisis Terjemahan Ungkapan Eufemisme dan Disfemisme pada Teks Berita Online BBC dalam jurnal ISSN 2527-2969. Penelitian relevan kelima oleh Elisa Nurul Laili berjudul Disfemisme dalam Perspektif Semantik, Sosiolinguistik, dan Analisis 
Wacana dalam jurnal ISSN 2442- 3823. Volume 12 nomor 2.

\section{METODE PENELITIAN}

Pendekatan penelitian yang digunakan untuk menganalisis bentuk eufemisme dan disfemisme yang terdapat dalam judul berita dalam surat kabar harian BALIKPAPAN POS yaitu pendekatan semantik leksikal. Pateda (2010, p. 74) menjelaskan bahwa Semantik leksikal adalah kajian semantik yang lebih memuaskan pada pembahasan sistem makna yang terdapat dalam kata.

Jenis penelitian yang digunakan dalam penelitian ini adalah penelitian kualitatif. Penelitian kualitatif merupakan penelitian yang ditunjukkan untuk mendeskripsikan dan menganalisis sebuah data sehingga hasil yang didapat lebih menekankan makna. Gunawan (2015, p. 80) menjelaskan bahwa penelitian kualitatif menekankan analisis proses dari proses berpikir secara induktif yang berkaitan dengan dinamika hubungan antarfenomena yang diamati dan senantiasa menggunakan logika ilmiah. Penelitian kualitatif bertujuan mengembangkan konsep sensitivitas pada masalah yang dihadapi, menerangkan realitas yang berkaitan dengan penelusuran teori dari bawah dan mengembangkan pemahaman akan satu atau lebih dari fenomena yang dihadapi.

Penelitian ini dilakukan untuk menemukan dan mendeskripsikan, makna dari bentuk serta fungsi penggunaan eufemisme dan disfemisme tersebut. Seperti halnya, mendeskripsikan penggunaan eufemisme dan disfemisme dalam judul berita surat kabar harian BALIKPAPAN POS periode April-Mei 2018. Penelitian ini akan mendeskripsikan atau menganalisis judul berita surat kabar harian BALIKPAPAN POS untuk mendapatkan hasil penelitian berupa bentuk kata dan fungsi dari penggunaan eufemisme dan disfemisme. Segala informasi data dalam penelitiannya menempuh tahap- tahap antara lain penyediaan kata, klasifikasi data, analisis data serta memberikan kesimpulan.

Ulfatin (2014, p. 179) menyatakan bahwa data adalah segala fakta dan angka yang dapat dijadikan bahan untuk menyusun suatu informasi. Data dalam penelitian diperoleh dari subyek yang disebut sumber data. Data di dalam penelitian ini ialah berbentuk judul surat kabar harian BALIKPAPAN POS.

Data dalam penelitian ini yaitu berbentuk kata dalam suatu kalimat yang menjadi judul sebuah berita di dalam surat kabar harian BALIKPAPAN POS. Arikunto (2006, p. 129) menjelaskan bahwa sumber data dalam penelitian adalah subjek dari mana data dapat diperoleh.

Sumber data di bagi menjadi dua sebagai berikut.

a. Sumber primer

Sumber data yang langsung memberikan data kepada pengumpul data. Data primer pada penelitian ini ialah surat kabar berisikan judul-judul berita yang dimuat.

Surat kabar BALIKPAPAN POS periode bulan April-Mei 2018. Surat kabar dijadikan sumber data dikarenakan surat kabar memiliki peranan penting di dalam pengembangan sebuah bahasa, termasuk bahasa Indonesia. Bahasa di surat kabar menjadi gambaran suatu bahasa yang berkembang di masyarakat bahkan menjadi panutan bagi pembaca. Kata, istilah, tata cara penulisan di surat 
kabar akan menjadi perhatian bahkan panutan bagi pembacanya untuk penggunaan bahasa dalam kehidupan sehari- hari.

\section{b. Sumber sekunder}

Sumber yang tidak langsung memberikan data kepada pengumpul data. Data sekunder pada penelitian ini berupa skripsi, jurnal, dan buku yang berkaitan dengan analisis eufemisme dan disfemisme.

Pengumpulan data dalam penelitian ini ialah peneliti menggunakan metode simak dengan metode lanjutannya teknik catat. Bentuk bahasa yang digunakan dalam judul berita surat kabar harian BALIKPAPAN POS dibaca secara saksama untuk menentukan bentuk eufemisme dan disfemisme, serta manfaat eufemisme dan disfemisme. Hal ini dilakukan dengan menggunakan metode simak. Data yang telah dikumpulkan disimak guna menemukan bentuk eufemisme dan disfemisme. Kemudian, data tersebut diklasifikasikan dengan berdasarkan kriteria-kriteria yang telah ditentukan setelah itu dilakukan pencatatan dengan teknik catat. Penelitian kualitatif memerlukan instrumen dalam pengumpulan data. Instrumen yang digunakan ialah kartu data. Kartu data ini memudahkan peneliti untuk mengumpulkan atau memperoleh data yang dibutuhkan.

Adapun keuntungan yang didapat peneliti dapat segera menganalisis data yang diperoleh. Sugiyono (2015, p. 148) menyatakan bahwa penelitian kualitatif, instrumen penelitian yaitu dimulai dari pembuatan tabel pengkodean data yang digunakan sebagai instrumen tambahan.

Penelitian ini akan menggunakan kriteria keabsahaan data yaitu kredibilitas (derajat kepercayaan) dengan teknik pemeriksaan sebagai berikut.

1) Ketekunan/Keajegan Pengamatan Mencari suatu usaha membatasi berbagai pengaruh. Mencari apa yang dapat diperhitungkan dan apa yang tidak dapat. Ketekunan pengamatan bermaksud menemukan ciri-ciri dan unsur-unsur dalam situasi yang sangat relevan dengan persoalan atau isu yang sedang dicari dan kemudian memusatkan diri pada hal-hal tersebut secara rinci.

2) Pemeriksaan Sejawat Melalui Diskusi Moleong (2014, p. 332) menyatakan bahwa teknik ini dilakukan dengan cara mengekspos hasil sementara atau hasil akhir yang diperoleh dalam bentuk diskusi dengan rekan- rekan sejawat. Teknik ini maksud sebagai salah satu teknik pemeriksaan keabsahan ialah untuk membuat agar peneliti tetap mempetahankann sikap terbuka dan kejujuran. Dalam diskusi analitik tersebut kemelencengan peneliti disingkap dan pengertian mendalam ditelaah yang nantinya menjadi dasar bagi klarifikasi penafsiran.

Teknik analisis data yang digunakan pada penelitian ini ialah analisis data menurut Miles dan Huberman, Sujarweni (2014, p. 35) sebagai berikut.

1) Reduksi Data

Data yang diperoleh ditulis dalam bentuk laporan atau data yang terperinci. Laporan yang disusun berdasarkan data yang diperoleh direduksi, dirangkum, dipilih hal-hal yang pokok, difokuskan pada hal-hal yang epnting.

2) Penyajian Data

Miles (Sujarweni, 2014, p 35) menyatakan bahwa data yang diperoleh dikategorikasasikan menurut pokok permasalahan dan dibuat dalam bentuk matriks sehingga memudahkan peneliti 
untuk melihat pola-pola hubungan datu data dengan data lainnya.

3) Penyimpulan dan Verifikasi

Miles (Sujarweni, 2014, p 35) menyatakan bahwa kegiatan penyimpulan merupakan langkah lebih lanjut dari kegiatan reduksi dan penyajian data. Data yang sudah direduksi dan disajikan secara sistematis akan disimpulkan sementara. Penelitian ini menggunakan teknik diskusi teman sejawat yang bahwasanya dapat menyimpulkan sementara dan memverifikasi sebelum dilakukan nya penarikan kesimpulan akhir.

4) Kesimpulan Akhir

Miles (Sujarweni, 2014, p 36) menyatakan bahwa kesimpulan akhir diperoleh berdasarkan kesimpulan

sementara yang telah diverifikasi. Kesimpulan final ini diharapkan dapat diperoleh setelah pengumpulan data selesai.

\section{HASIL DAN PEMBAHASAN}

Hasil penelitian tersebut akan dibahas berdasarkan masalah yang telah ditemukan yaitu bentuk serta manfaat eufemisme dan disfemisme secara berkelanjutan. Adapun dalam bentuk pembahasan ini dideskripsikan hasil penelitian dari aspek bentuk berupa kata yang diperoleh dari judul berita surat kabar harian BALIKPAPAN POS periode April-Mei 2018.

\section{1) Eufemisme Bentuk Kata Benda (adjektiva) untuk Kesopanan dan Kenyamanan}

Berikut pembahasan data dari penelitian yang diperoleh berupa eufemisme berbentuk kata benda (adjektiva) untuk kesopanan dan kenyamanan.

Data 2 : 02/08/04

"Warga RT 4 Teritip Swadaya Perbaiki Drainase"
Judul berita pada data (02/08/04) mengenai informasi bahwa warga RT 4 Teritip sedang melakukan perbaikan pada drainase di daerahnya. Berdasar dari isi berita pada data $(02 / 08 / 04)$ warga setempatlah yang memiliki inisiatif mengenai kegiatan tersebut. Kegiatan tersebut dilakukan dengan gotong royong antara warga.

Data (02/08/04) menggunakan eufemisme berbentuk kata benda (nomina) karena dapat menduduki tempat objek juga menyatakan suatu wujud yang dapat dilihat. Bentuk eufemisme pada data (02/08/04) bereferensi benda yang dihaluskan dan terdengar lebih santun yaitu drainase. Drainase disebut kata benda karena dapat dilihat dan disentuh.

KBBI (2018) drainase yaitu; penyaluran air; saluran air. Saluran air yang terdapat di kawasan rumah penduduk sebagai tempat lalunya air menuju muara sungai juga sebagai pencegah banjir. Secara leksikal drainase memiliki makna tempat saluran air yang terdapat di wilayah rumah penduduk. Drainase merupakan eufemisme karena bahasanya lebih halus dan santun.

Manfaat penggunaan kata drainase ialah untuk kesopanan dan kenyamanan. Sutarman (2013, p. 110) menyatakan bahwa kesopanan adalah upaya yang dilakukan agar dinilai positif oleh orang lain. Kata drainase digunakan agar lebih sopan dan santun serta dapat dinilai positif Penggunaan kata drainase lebih halus dibanding kata parit.

\section{2) Eufemisme Bentuk Kata Kerja (verba) untuk Kesopanan dan Kenyamanan}

Berikut ditampilkan data dari penelitian yang diperoleh berupa eufemisme berbentuk kata kerja (verba) untuk kesopanan dan kenyamanan.

Data 7 : 07/19/04

"Muara Sungai Jadi Sempit karena Reklamasi" 
Judul pada data (07/19/04) menunjukkan berita mengenai muara sungai berubah menjadi sempit yang disebabkan adanya reklamasi.

Data (07/19/04)

menggunakan eufemisme berbentuk kata kerja (verba) karena menyatakan perbuatan dan bereferensi aktivitas karena merupakan suatu aktivitas yang dilakukan manusia yang menyangkut pemerintah atau pemimpin, yaitu reklamasi.

KBBI (2018) reklamasi adalah pemanfaatan daerah yang semula tidak berguna untuk memperluas tanah (pertanian) atau tujuan lain, misalnya dengan cara menguruk daerah rawarawa, pengurukan (tanah). Secara leksikal reklamasi bermakna kegiatan yang dilakukan dengan tujuan menambah luasan daratan untuk suatu aktivitas yang sesuai di wilayah dan juga dimanfaatkan untuk keperluan tertentu atau reklamasi adalah proses pembuatan daratan baru dari dasar laut atau dasar sungai. Reklamasi adalah bahasa halus dari pengurukan tanah atau penimbunan. Manfaat penggunaan kata reklamasi ialah untuk kesopanan dan kenyamanan. Sutarman (2013, p. 110) menyatakan bahwa kesopanan adalah upaya yang dilakukan agar dinilai positif oleh orang lain. Kata reklamasi digunakan agar lebih sopan dan santun karena jika digunakan kata pengurukan tanah maka timbul pikiran negatif oleh pembaca

\section{3) Eufemisme Bentuk Kata Sifat (nomina) untuk Kesopanan dan Kenyamanan}

Berikut ditampilkan data dari penelitian yang diperoleh berupa eufemisme berbentuk kata sifat (nomina) untuk kesopanan dan kenyamanan.

\section{Data 15 : 15/06/04}

"Sungai Nenang Tercemar"

Data $(15 / 06 / 04)$ mengenai berita sungai yang tercemar karena bocornya pipa minyak pertamina. Sungai nenang membuat resah warga karena bau yang keluar dari tercemarnya sungai tersebut. Data (15/06/04)

menggunakan eufemisme berbentuk kata sifat (ajektiva) kata dasarnya cemar dan dibubuhi morfem pembentuk kata sifat yaitu ter-, membentuk kata sifat yaitu tercemar dan menyatakan sifat atau hal keadaan sebuah benda/sesuatu yaitu keadaan sungai yang tercemar. Serta bentuk eufemisme pada data (15/06/04) yaitu kata tercemar.

KBBI (2018) tercemar yaitu menjadi cemar (rusak, tidak baik lagi), ternoda. Secara leksikal makna tercemar ialah kondisi sungai yang menjadi rusak atau tidak baik lagi yang diakibatkan oleh kebocoran pipa minyak. Penggunaan kata tercemar lebih halus dibanding kata ternoda atau rusak.

Manfaat penggunaan kata tercemar adalah untuk kenyamanan dan kesopanan. Sutarman (2013, p. 110) menyatakan bahwa kesopanan adalah upaya yang dilakukan agar dinilai positif oleh orang lain melalui sikap, perbuatan, perkataan, maupun penampilan. Penggunaan kata tercemar lebih halus dibanding kata ternoda atau rusak.

\section{4) Disfemisme Bentuk Kata Benda (adjektiva) untuk Penulisan Judul Berita di Media Massa}

Berikut ditampilkan data dari penelitian yang diperoleh berupa eufemisme berbentuk kata benda (adjektiva) untuk kesopanan dan kenyamanan.

\section{Data 18 : 18/28/04}

"Kabar Gembira untuk Guru di Pelosok" Data (18/28/04) berita mengenai 2.000 guru di wilayah pelosok mendapatkan subsidi kepemilikan rumah lewat Fasilitas Likuiditas Pembiayaan Perumahan (FLPP). Selain itu, terdapat pula fasilitas perbaikan rumah.

Data (18/28/04)

menggunakan disfemisme berbentuk kata benda (nomina) karena dapat menyatakan nama dari seseorang, tempat, atau semua benda dan segala 
yang dibendakan, yaitu kata pelosok. Berdasarkan data (18/28/04) pelosok menyatakan nama tempat terpencil atau jauh dari keramaian kota serta suatu tempat yang mengalami keterbatasan fasilitas.

KBBI (2018) pelosok yaitu tempat yang jauh atau yang tidak mudah didatangi, penjuru. Secara leksikal pelosok berdasarkan data (18/28/04) memiliki makna suatu tempat yang terpencil, jauh dari keramaian kota serta mengalami keterbatasan fasilitas. Tidak banyak orang mau untuk mengabdi ke pelosok.

Manfaat penggunaan kata pelosok ialah untuk penulisan judul berita di media massa. Manfaat disfemisme sebagai penulisan judul berita di media massa adalah untuk menjadi daya tarik para pembaca.

\section{5) Disfemisme Bentuk Kata Kerja (verba) untuk Penulisan Judul Berita di Media Massa}

Berikut ditampilkan data dari penelitian yang diperoleh berupa eufemisme berbentuk kata kerja (verba) untuk kesopanan dan kenyamanan.

\section{Data 21 : (21/02/04)}

"Wanita Ditemukan Tewas

Judul pada data (21/02/04) menunjukkan berita mengenai seorang wanita yang ditemukan tewas tergantung. Berdasarkan isi berita dari judul data (21/02/04) wanita tersebut tewas tergantung dengan seutas tali di salah satu ruangan stadion baru di kilometer 6 Jalan Kusuma Bangsa, Tanah Grogot. Pertama kali ditemukan oleh petugas jaga pembangunan stadion.

Data (21/02/04) menggunakan disfemisme berbentuk kata kerja (verba) karena dapat menyatakan suatu tindakan, keberadaan, pengalaman, atau pengertian dinamis lainnya, yaitu kata tewas. Pada eufemisme berbentuk kata tewas wanita di dalam isi berita menggantung leher atau melakukan bunuh diri hingga menghilangkan nyawanya.
KBBI (2018) tewas adalah mati (dalam perang, bencana, dan sebagainya). Tewas dipergunakan pada kalimat yang berkaitan dengan tindak kriminal atau pembunuhan. Secara leksikal makna dari kata tewas ialah hilangnya nyawa seseorang yang disebabkan oleh peristiwa- peristiwa tertentu seperti , berdasar isi berita pada data $(21 / 02 / 04)$ disebabkan karena wanita tersebut menggantung dirinya hingga berujung kematian

Manfaat penggunaan kata tewas ialah untuk penulisan judul berita di media massa. Manfaat disfemisme sebagai penulisan judul berita di media massa adalah untuk menjadi daya tarik para pembaca. Penggunaan kata tewas pada penulisan di judul berita akan menjadi daya tarik karena tewas yang artinya seseorang yang telah meninggal dunia dengan keadaan yang tidak wajar seperti dibunuh atau bunuh diri.

\section{6) Disfemisme Bentuk Kata Sifat (nomina) untuk Penulisan Judul Berita di Media Massa}

Berikut ditampilkan data dari penelitian yang diperoleh berupa eufemisme berbentuk kata sifat (nomina) untuk kesopanan dan kenyamanan.

Data 34 : (34/14/04)

"Bau Menyengat Masih Tercium"

Judul berita pada data (34/14/04) mengenai bau menyengat masih tercium, bau yang dimaksud berdasar isi berita pada data (34/14/04) ialah bau minyak akibat kebocoran pipa yang terjadi. Bau minyak menyengat diakui warga membuat sesak nafas. Belum ada cara untuk menghentikan bau yang menyengat tersebut. Warga hanya menggunakan masker untuk melindungi pernapasan mereka.

Data (34/14/04)

menggunakan disfemisme berbentuk kata sifat (adjektiva) karena menyatakan sifat atau hal keadaan sebuah benda/sesuatu, yaitu kata bau. Berdasarkan data $(34 / 14 / 04)$ kata bau 
menyatakan sifat pada keadaan yang terjadi akibat kebocoran pipa.

KBBI (2018) bau yaitu apa yang dapat ditangkap oleh indra pencium (seperti anyir, harum, busuk). Secara leksikal bau memiliki makna tak terlihat namun dapat tertangkap oleh indra pencium atau hidung, serta bau memiliki jenisnya yaitu bau yang sedap dan bau yang tidak sedap. Kata bau dapat dihaluskan atau digantikan menjadi kata aroma. Manfaat penggunaan kata bau ialah untuk penulisan judul berita di media massa. Manfaat disfemisme sebagai penulisan judul berita di media massa adalah untuk menjadi daya tarik para pembaca. Penggunaan kata bau pada penulisan di judul berita akan menjadi daya tarik karena bau artinya aroma yang tercium dan memiliki sebab dan akibat

\section{KESIMPULAN}

Dalam penelitian dan pembahasan terhadap judul berita surat kabar harian BALIKPAPAN POS April- Mei 2018, peneliti dapat menarik kesimpulan bahwa dengan adanya fokus penelitian dan rumusan masalah yang ditentukan. Penggunaan eufemisme dan disfemisme pada judul berita surat kabar harian BALIKPAPAN POS periode April-Mei 2018 berbentuk kata benda, kata kerja, dan kata sifat. Eufemisme berbentuk kata benda terdapat enam data, eufemisme berbentuk kata kerja delapan data, eufemisme berbentuk kata sifat tiga data.

Berdasarkan dari tujuh belas data yang ditemukan dengan manfaat yang sama yaitu untuk kesopanan dan kenyamanan. Penggunaan disfemisme berbentuk kata benda terdapat tiga data, disfemisme berbentuk kata kerja tiga belas data dan disfemisme berbentuk kata sifat dua data. Berdasarkan dari delapan belas data ditemukan dengan manfaat yang sama yaitu untuk penulisan judul berita di media massa. Hal ini menunjukkan bahwa dari tiga puluh lima data yang ditemukan dengan penggunaan eufemisme dan disfemisme cenderung pada eufemisme dan disfemisme berbentuk kata kerja dan penggunaan disfemisme berbentuk kata kerja lebih dominan digunakan karena kata kerja banyak digunakan pada judul berita, disfemisme digunakan agar kata kerja tersebut mendapat penekanan sehingga pembaca paham akan maksud dari judul berita tersebut.

\section{DAFTAR PUSTAKA}

Allan, K., \& Burridge, K. (1991). Euphemism \& Dysphemism : Language Used As Shield And Weapon. New York : OXFORD UNIVERSITY PRESS.

Arikunto. (2006). Prosedur Penelitian Suatu Pendekatan Praktik. Jakarta: PT. Rineka Cipta.

Aslinda, \& Syafyahya. (2007). Pengantar Sosiolinguistik. Bandung: PT. Refika Aditama.

Bahri, S. (2014). Eufemisme dan Disfemisme dalam Teks Berita pada Surat Kabar Pikiran Rakyat sebagai Bahan Pembelajaran Bahasa Indonesia di SMA serta Model Pembelajarannya. Wacana Didaktika , 28-39

Barus, S. W. (2011). Jurnalistik. Jakarta: Penerbit Erlangga.Chaer, A. (2010). Bahasa dan Jurnalistik. Jakarta: Rineka Cipta. Chaer, A. (2013). Pengantar Semantik Bahasa Indonesia. Jakarta: PT. Rineka Cipta.

Chaer, A., \& Agustina, L. (2010). Sosiolinguistik. Jakarta: PT. Rineka Cipta.

Gunawan. (2015). Metode Penelitian Kualitatif. Jakarta: PT. Bumi Aksara. 
Khasan, A. M., Sumarwati, \& Setiawan, B. (2014). Pemakaian Disfemisme dalam Berita Utama Surat Kabar Joglo Semar. BASASTRA Jurnal Penelitian Bahasa, Sastra Indonesia dan pengajarannya , 112

Laili, E. N. (2017). Disfemisme Dalam Perspektif Semantik,

Sosiolinguistik, dan Analisis. Lingua , 110-118.

Laili, E. N. (2013). Disfemisme pada Wacana Lingkungan: Sebuah Kajian Ekolinguistik Kritis dalam Media Massa di Indonesia. Mabasan .

Meilasari, P., Nababan, M., \& Djatmika. (2016). Analisis Terjemahan Ungkapan Eufemisme dan Disfemisme pada Teks Berita Online BBC. Linguistik, 336-358.

Moleong, L. (2014). Metodologi Penelitian Kualitatif. Bandung: PT. Remaja Rosdakarya.

Muslich. (2007). Tata Bentuk Bahasa Indonesia. Jakarta: PT. Bumi Aksara.

Pateda, M. (2010). Semantik Leksikal. Jakarta: Rineka Cipta.

Sugiyono. (2015). Metode Penelitian Pendidikan Pendekatan Kuantitatif, Kualitatif dan $R \& D$. Bandung: Pustaka Buku Press.

Sutarman. (2013). Tabu Bahasa dan Eufemisme. Surakarta: Yuma Pustaka.

Tarigan, P. D. (2013). Pengajaran Gaya Bahasa. Bandung: CV Angkasa.

Ulfatin. (2014). Metode Penelitian Kualitatif di Bidang Pendidikan: Teori dan Aplikasinya. Malang: Bayumedia Publishing. 